\title{
Blogs og online-undervisning Introduktion til et asynkront, dialogisk kommunikationsværktøj
}

\author{
Carsten Jessen \\ Institut for pædagogisk antropologi \\ Danmarks Pædagogiske Universitet \\ cj@dpu.dk \\ http://www.dpu.dk
}

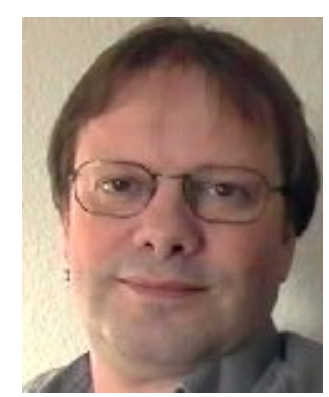

Carsten Jessen er lektor ved Institut for pæedagogisk antropologi ved Danmarks Pæedagogiske Universitet og tilknyttet forskningsprogrammet Medier og IT i lceringsperspektiv samme sted. Han underviser bl.a. ved den tvceruniversitcere Masteruddannelse i Medier og IKT (MIL). Han har mere end ti års erfaring med fjernundervisning inden for forskellige fagområder, og han har publiceret bøger og artikler inden for områderne medier, it og læering, computerspil og kultur.

I online-undervisning er elektroniske konferencer i dag det dominerede kommunikationsredskab til dialoger verden over (Paulsen 2002). Disse redskaber, der grundlæggende ikke har ændret form siden 1980'erne, er funktionelle, fordi de både er nemme at anvende og giver mulighed for den asynkrone, dialogiske kommunikation, der er krumtappen i de fleste former for onlineundervisning. Elektroniske konferencer har gennem en længere årrække vist deres brugbarhed i praksis, særligt når der som et led i undervisningen bruges tid og kræfter på at lære de studerende en hensigtsmæssig brug (Sorenson \& Takle 2002). Konferencer har imidlertid tekniske begrænsninger, som kan lægge bånd på dialogerne ved at rammesætte deltagernes udfoldelsesmuligheder i en stram kommunikationsstruktur, der ligger relativ langt fra den måde, diskussioner og samtaler normalt forløber på. Diskussioner bliver eksempelvis hurtigt uoverskuelige og tidskrævende at følge, hvis deltagerne lader associationer og tankespring dominere dialogerne i et voksende antal tråde og undertråde. Derfor kræver en fornuftig anvendelse af konferencer en forholdsvis høj disciplin hos deltagerne, og mens det kan være en pædagogisk fordel i mange tilfælde, at man holder sig strikt til emnet, så er det på den anden side en begrænsning i en akademisk uddannelse, hvis der ikke er rum for andre typer dialoger.

Tendensen til at skabe uoverskuelighed går igen i relation til deltagerne som personer. Konferencer har deres force i at være et emnecentreret kommunikationsredskab, men det betyder samtidig, at det er vanskeligt at få øje på den enkelte deltager som selvstændig person i indlæg, der er spredt ud over en lang række emner og tråde, og det er en akilleshæl i forbindelse med online-undervisning, hvor deltagerne ofte kun kender lidt til hinanden. Det fører nemt til, at deltagerne føler sig identitetsløse og alene, med mindre de skriver ofte og meget, hvorved de løber en stor risiko for at blive for kendte og stemplet som egocentriske af de øvrige deltagere.

Online-undervisning har ligesom tilstedeværelsesundervisning brug for forskellige dialogformer, og derfor behøves forskellige kommunikationsredskaber, fordi disse hver for sig støtter bestemte former for dialoger og modarbejder andre. Som underviser har man i dag som regel ikke andre valgmuligheder end de elektroniske konferencer, som er standarden til asynkrone dialoger i alle gængse systemer til online-undervisning. Men bl.a. af ovennævnte grunde er der anledning til at søge efter andre, supplerende kommunikationsredskaber, og der er i alt fald ét oplagt tilbud i form af blogs eller weblogs, som gennem de seneste år har bredt sig på internettet. Blogs, der også tiltrækker sig 
stigende interesse i forbindelse med online-undervisning (Brooks, Nichols \& Priebe 2004; Farmer 2004; Fiedler 2004), er ikke nødvendigvis det ideelle kommunikationsredskab, men de sætter fokus på andre kommunikative aspekter end konferencer, og de lægger dermed op til andre måder at kommunikere på.

\section{Et nemt redskab til publicering}

En blog udmærker sig ved at være et personcentreret kommunikationsværktøj med mange anvendelsesmuligheder, der strækker sig fra personlige dagbøger over personlig portfolio og forskningslogbøger til online-journalistik. En voksende del af debatterne på internettet foregår i dag via blogs. Som en understregning af den betydning, der i mange kredse tillægges fænomenet, kan det nævnes, at de siges at være i gang med at forandre journalistikken for altid, fordi de traditionelle medier har fået stærk konkurrence fra græsrødder og ikke længere kan fungere som filter eller gatekeeper for nyheder (Willis \& Bowman 2004). Det kan synes lidt vel meget at tilskrive et simpelt it-værktøj, der teknisk kan defineres som følger:

En weblog (eller blog) er en web-side, eller en del af et web-sted, som opdateres jæunligt med korte tekster (kaldet poster), hvoraf den til enhver tid nyeste står øverst. (Wikipedia 2004)

I realiteten er blogs det helt enkle værktøj til web-publicering, hvor brugerne ikke behøver andet end en browser for at kunne udgive, hvilket helt har fjernet de tekniske barrierer, der hidtil har forhindret folk i at publicere til det globale internetpublikum. Weblogs gør det derfor muligt for alle og enhver at publicere både tekst, billeder (fotoblogs, moblogs), lyd (audioblogs) og video (videoblogs), og det kan næppe undgå at få betydning for kommunikation og kontaktflader på nettet og dermed for global kommunikation som sådan.

\section{Løst koblede systemer}

Muligheden for at publicere gør det naturligvis ikke i sig selv, og blogs er ikke defineret alene ved at være et nemt værktøj, men også ved måden, hvorpå publiceringen foregår. Som det fremgår af definitionen, er det normalt at publicere ofte og med kortfattede tekster, og det er tillige almindeligt, at en blog som hovedregel skrives af én person. Der findes også gruppe-blogs, men de har ofte karakter af nyhedsmedier. Oprindeligt var blogs blot en samling web-links forsynet med korte kommentarer af blog-forfatteren Dette træk er fastholdt i de fleste weblogs, men kommentarerne er i dag længere og mere refleksive. Det er almindeligt, at en post i en blog linker til poster i andre blogs eller til andre kilder på nettet, såsom netbaserede nyhedsmedier, som bloggens forfatter kommenterer og elaborerer over. En sådan post er så igen kilde og inspiration for andre blog-forfattere, og således udvikler der sig en løbende dialog, der spreder sig som ringe i vandet. På internettet sker dette selvsagt uorganiseret og uformelt, men over tid danner der sig klynger af bloggere, som et ideelt eksempel på nettets mulighed for at danne løst koblede systemer. Blogs binder på denne måde nettets brugere sammen via personlige kommentarer, perspektiveringer og meningsudvekslinger, og det er bl.a. disse aspekter, der tiltrækker opmærksomhed i relation til online-undervisning.

\section{Really Simple Syndication}

I sig selv er en weblog blot en web-side blandt alle de andre sider på nettet og dermed behæftet med de samme velkendte problemer, herunder ikke mindst at læsere aktivt skal opsøge dem. I kraft af den jævnlige opdatering kan blogs dog ikke helt sammenlignes med de mange statiske sider, som brugere møder andre steder og ofte hurtigt mister interessen for. Når blogs er slået igennem som mere end et redskab til udgivelse og envejskommunikation skyldes det imidlertid udviklingen af tekniske løsninger, som har gjort det nemt for brugerne at forbinde de individuelle blogs med hin- 
anden, og det sker vel at mærke på den enkelte brugers eget initiativ og ud fra brugerens suveræne valg, uden at det er nødvendigt at blande moderatorer eller teknikere ind i sagen. Denne fleksibilitet er lysår fra de stramme tekniske tøjler, der endnu findes i de fleste learning managment systemer. To af disse tekniske løsninger skal kort beskrives i det følgende, herunder en ny standard for syndikering, som måske er en af de vigtigste evolutioner på internettet, der er set længe. RSS, som står for "Rich Site Summary”, men som regel betegnes "Really Simple Syndication”, er kort fortalt en standard for, hvordan overskrifter og korte resumeer af et indhold på en web-side rent teknisk præsenteres (Pilgrim 2002). RSS gør det derved nemt at få overblik og holde sig orienteret om ændringer og nyheder på nettet. Via særlige programmer, RSS Newreaders, er det fx muligt at abonnere på weblogs og få vist overskrifter, når der er nye poster, som så kan nås via et enkelt museklik. RSS, der primært er udviklet som et græsrodsinitiativ, blev implementeret i blogs fra begyndelsen, men standarden er i dag taget i anvendelse i mange andre programmer, bl.a. open source-browseren FireFox, og anvendes af mange medier som fx BBC, DR og TV2.

RSS-funktion er ikke begrænset til newreaders og blogs, for teknikken kan i princippet implementeres i alle programtyper og fx indbygges i elektroniske konferencer. Det er endnu kun sket i få tilfælde, typisk i open source-systemer, men lignende funktionaliteter ses i stigende omfang i gængse learning management systemer, hvor teknikken anvendes til at få et hurtigt overblik over, hvad der er sket, siden brugeren sidst var på nettet. I forbindelse med blogs anvendes RSS imidlertid ofte til mere end det. En newsreader kan fx indstilles til løbende at scanne de kilder, den enkelte bruger vælger at følge, så man øjeblikkeligt bliver gjort opmærksom på nyt stof med en meddelelse på skærmen. Det kan naturligvis bidrage til overflod af information, men det kan på den anden side medvirke til, at en bruger oplever at være en del af et aktivt fællesskab. For deltagere i onlineundervisning kan det utvivlsomt føles langt mindre ensomt med løbende livstegn fra medstuderende, ligesom det også kan anspore til aktiv deltagelse i igangværende dialoger.

\section{Trackback}

RSS er et eksempel på, hvordan blog-fænomenet har udviklet sig i et tæt samspil mellem brugere og teknikere, og det samme er tilfældet for en anden teknisk nyudvikling, som har betydning for sammenhængskraften mellem individuelle blogs og dermed for dannelsen af løst koblede systemer, nemlig muligheden for at links peger "fremad" i tid. For den individuelle blogger er det et oplagt problem, at man ikke uden videre kan vide, om andre bloggere efterfølgende kommenterer det, man skriver. ”Trackback”, ”pingback” eller ”linkback”, som den tekniske løsning kaldes, er egentlig kontraintuitiv, for som almindelig bruger af internettet opleves det umiddelbart som om alle links peger frem og bringer en videre, men i realiteten peger links jo altid tidsmæssigt "bagud”, fordi det, der linkes til, nødvendigvis må eksistere, før man kan oprette en henvisning til det. Trackbackteknikken er en løsning på dette problem. Når en blogger kommenterer og linker "bagud” til en post i en anden blog, sørger trackback-teknikken for, at der automatisk indsættes et link ved den post, der kommenteres. Derved får den enkelte blogger øjeblikkelig svar på det brændende spørgsmål: "Hvem citerer mig?” Samtidig er det for andre læsere mulighed for at følge, hvordan en debat udvikler sig.

\section{Nye forbindelser}

Trackback demonstrerer et centralt træk ved blogs og deres anvendelse på nettet: Evnen til at skabe nye forbindelser og netværk mellem brugerne. På internettet generelt sker det på brugernes initiativ, frivilligt og i evigt skiftende konstellationer, men der findes i dag også blog-systemer med et stærkt socialt element indbygget. Det bedste eksempel på dette er LiveJournal (www.livejournal.com) med over tre millioner brugere. I systemet kombineres personlige blogs med en række andre brugervenlige redskaber, der med anvendelsen af ovennævnte teknikker støtter dannelsen af fællesskaber, 
herunder muligheden for at den enkelte blogger nemt kan forbinde sin blog med andre, udvalgte blogs. På den måde dannes sammenslutninger og interessefællesskaber, eksempelvis meget enkelt ved at den individuelle blogger opretter en "friends list", som automatisk scannes for nye poster, eller ved at de enkelte sammenslutninger får en web-side, hvor alle nye poster fra deltagerne automatisk præsenteres (se Raynes-Goldie (2004) for en nærmere beskrivelse).

Nogle af fællesskaberne på LiveJournal er rent virtuelle, mens andre mikser det virtuelle med det fysiske, men fælles for dem er, at de dannes uformelt og udvikler sig ved knopskydning. LiveJournals brugere er for flertallets vedkommende studerende, og Raynes-Goldie anfører, at kommunikationen i systemet dækker alle mulige og umulige temaer, herunder diskussioner af faglig og filosofisk karakter, men også mere prosaiske emner som vurderinger af undervisningsforløb og underviseres kvalitet. Det personcentrerede udgangspunkt gør, at disse vidt forskellige emner ikke optræder i adskilte virtuelle rum, men er blandet i de enkelte deltageres blog, hvilket gør, at den enkelte blogger træder frem som person. I weblogs er der i det hele taget en generel tendens til, at der på grund af det personcentrerede ofte ses personlige vurderinger og indlæg, der handler om den enkelte bloggers dagligdag (Blood 2002). Herved bliver det virtuelle kommunikationsrum mere lig de fysiske kommunikationsrum, hvor det formelle og det uformelle, det faglige og det personlige naturligt er kombineret. Et godt eksempel på dette er, at den erfaringsudveksling, der foregår, når studerende indbyrdes diskuterer undervisningen og underviserne fx i pauserne, også sker i de virtuelle rum, der dannes via LiveJournals blogs. I forbindelse med onlineundervisning er en sådan erfaringsudveksling i mange tilfælde fraværende eller vanskelig at få etableret, da den umiddelbart kan forekomme fagligt set uvedkommende og måske ligefrem usaglig i skriftlig form. I mundtlig kommunikation forekommer det derimod mere naturligt både inden for og på tværs af hold og årgange. Denne mangel på erfaringsudveksling er måske den største svaghed ved online-undervisning, fordi den kan hindre de studerende i at skabe et rum for uformelle meningsforhandlinger i tilknytning til undervisningen (Jessen 2005). Det kan medføre en øget individualisering, som gør det er vanskeligt for den enkelte studerende at afstemme forventninger til både studiet og uddannelsen, hvilket både kan føre til et øget pres på underviserne og til en øget formalisering af undervisningen, som har både faglige og praktiske konsekvenser. Det skal understreges, at blogs ikke uden videre kan fjerne det problem, men de kan bringe os på sporet af en løsning.

I LiveJournal er der i øvrigt mange eksempler på, at den virtuelle kommunikation bringer de studerende, der deltager i tilstedeværelsesundervisning sammen, tættere på hinanden ved at åbne for løbende, asynkron kontakt. Selv om der er større mulighed for, at uformel meningsforhandling foregår mellem de studerende, når de er fysisk sammen, er der erfaringsmæssigt langt fra garanti for dette. I mange tilfælde kender deltagerne på et hold ikke meget til hinanden, men mødes blot til undervisningen og går derefter hver til sit.

\section{Læringsfællesskaber}

Både de tekniske og anvendelsesmæssige landvindinger for virtuel kommunikation, som weblogs repræsenterer, rummer nye muligheder for at initiere de aktive læringsfællesskaber, som set fra et konstruktivistisk perspektiv er den centrale ingrediens i al undervisning og læring. Effektiv kommunikation i form af god kontakt er alfa og omega, hvis sådanne fællesskaber skal kunne udvikle sig, og alt andet ufortalt, så er konferencer nok anvendelige til dette formål, men ikke ideelle. I en artikel om online-undervisning, konferencer og blogs peger James Farmer (2004) på et centralt problem ved konferencer via en tænkt, men sigende overføring af kommunikationsformen til tilstedeværelsesundervisning. I en fysisk kontekst ville det svare til, at de studerende én efter én og uafhængigt af hinanden mødte op i et tomt klasselokale og lagde en skriftlig besked til de andre studerende. Efterfølgende må de studerende så vende tilbage gentagne gange, for at se de medstuderendes responser, som måske, måske ikke er der. Farmer fører måske sagen ud i det groteske, men der 
er meget sandhed i billedet. Nødvendigheden af stor tålmodighed i kommunikationen var underforstået for et årti siden (hvor konferencer også meget præcist hed ”Bulletin Boards”), men kan ikke længere forventes, slet ikke fra de nye generationer, der er vant til at være online.

Farmer fremhæver i den nævnte artikel, at blogs synes at være bedre end konferencer til at indfri tre centrale betingelser for skabelsen af læringsfællesskaber, som han henter fra Garrison og Anderson (2003) og anvender som pejlepunkter. Der er tale om henholdsvis social presence, som vedrører deltagernes mulighed for at være socialt og følelsesmæssigt tilstede som personer, cognitive presence, der handler om deltagernes mulighed for at kunne konstruere og få anerkendt viden, samt teaching presence, der drejer sig om underviserens mulighed for at designe og påvirke læringsmiljøet. I relation til blogs er det indlysende, at social presence har gode vilkår i kraft at det personcentrerede. For så vidt det sociale aspekt ikke blot er et spørgsmål om, at den enkelte skal have indfriet et basalt behov for at være tilstede som person i et socialt samvær, men er et spørgsmål om, at det personlige og læringen er sammenhængende, er dette naturligvis af betydning også for cognitive presence. Her er det ikke som sådan det personcentrerede, der er det centrale, men i stedet hvad denne centrering betyder for kommunikationens og dialogernes karakter (jf. nedenfor om netværksstruktur og det dialogiske). I weblogs får den enkelte den personlige stemme, som ofte er fraværende i elektroniske konferencer, og i og med en sådan stemme kan dialogerne få et bredere register.

\section{Underviseren som person}

Social presence er ikke alene et forhold, der gælder de studerende i et læringsfællesskab, men i høj grad også underviserne. Farmer påpeger, at underviserne kommunikativt set er ligestillet med studerende i konferencer, og mens det kan ses som en fordel i nogle tilfælde, fx når underviseren ønsker at optræde i rollen som proceskonsulent, så begrænser ligestillingen underviserens mulighed for at indtage forskellige roller på en konstruktiv måde, herunder rollen som den med størst faglig indsigt. Erfaringsmæssigt er der således en klar tendens til, at en lærers faglige indlæg i en konferencetråd let risikerer at lukke for videre debat mellem de studerende, hvorfor læreren kan være tilbøjelig til at holde sig tilbage, uden at have alternative veje til at påvirke debatten. Et eksempel på, hvordan blogs bl.a. kan anvendes i online-undervisning, ligger indirekte i den definition af blogs, som en af pionererne på området, Dave Winer, har givet: A weblog is kind of a continual tour, with a human guide who you get to know (Winer). Set sådan er weblogs et nærmest ideelt redskab til at understøtte underviseren i rollen som den, der guider de studerende ind i et fagligt felt ved at være tilstede som en person, hvis faglige arbejde og refleksioner løbende kan følges gennem dennes personlige blog.

I tilstedeværelsesundervisning skifter undervisere som regel mellem flere roller, og denne fleksibilitet bør selvfølgelig også være til stede i online-undervisning, bl.a. som en valgmulighed mellem flere kommunikationsredskaber. Teaching presence handler generelt om fleksibilitet i såvel lærerrollen som på andre områder. Kernen er her at undgå alt for stramme tekniske bindinger fra forudprogrammerede systemer, så undervisningen kan tilrettelægges ud fra det konkrete behov. Weblogs er ikke den endelige løsning, for en sådan findes i sagens natur ikke, men de repræsenterer et skridt på vejen ved at gøre asynkron virtuel kommunikation mere fleksibel.

\section{Træstruktur og netværksstruktur}

Det mest interessant træk ved blogs både pædagogisk og kommunikationsmæssigt er, at de i kraft af deres tekniske opbygning er orienteret mod netværksdannelse og dannelse af åbne kommunikationsmønstre. Dialoger i blogs udvikler sig ofte i stil med mundtlige samtaler, hvor emner og temaer gennemgår en række metamorfoser undervejs i dialogen, alt afhængig af deltagernes ønsker og behov. Derved adskiller dialogerne sig fra de relativt strukturerede diskussioner i konferencer, som i 
højere grad ligner de mere formelle dialoger, der foregår i undervisningen. Mens indlæg i konferencer som regel forventes at holde sig til emnet og kommentere andres indlæg, så rummer formen i blogs større muligheder for associationer, spring, personlig vurdering og refleksioner. Forskellen mellem kommunikationsforløb i konferencer og blogs kan principielt set beskrives som forskellen mellem en klassisk træstruktur og en netværksstruktur, og det er næppe tilfældigt, at det også er en illustration af den rent tekniske forskel på de to redskaber, som er udviklet med et mellemrum på mere end et årti.

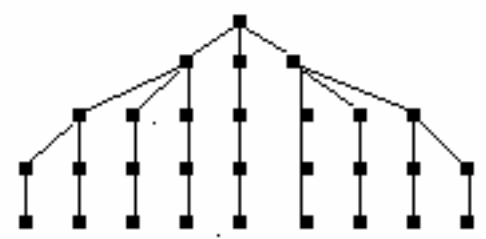

Figur1. Træstrukturen i elektroniske

konferencer med velordnede tråde

Den følgende illustration er resultatet af en empirisk analyse af en blog og dens forbindelser til andre blogs. Strukturen minder påfaldende om dem, man finder i diagrammer med analyser af kommunikation i sociale netværk i fysiske rum (se fx Scott 2000). Denne parallelitet mellem sociale netværk og de rent tekniske forbindelser i blogs (links og trackback) understreger de sociale og dialogiske potentialer, som blogs tilbyder med det personlige udgangspunkt og de teknisk set meget fleksible muligheder for at koble poster på kryds og tværs.

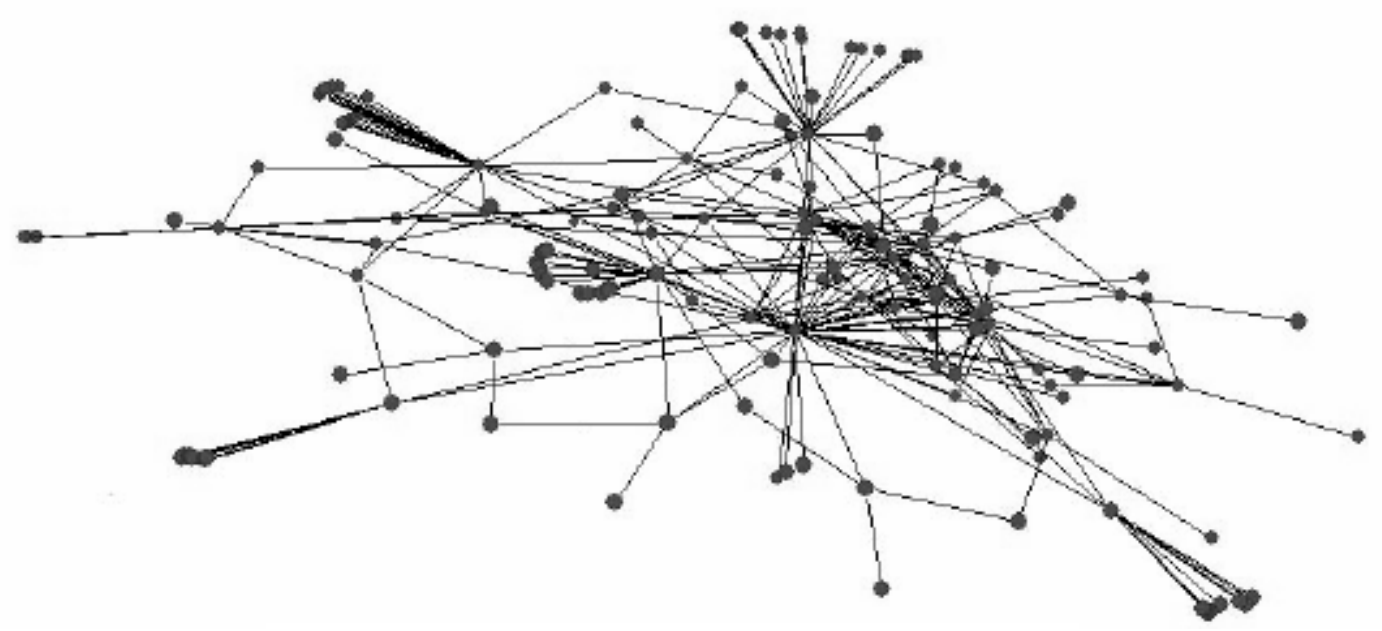

Figur 2. En illustration af links mellem blogs (Efimova \& Hendrick 2004)

\section{Kaotisk orden}

Overskuelighed og orden er næppe det første, der falder i øjnene ved en illustration som overstående, og i første omgang fremtræder blogs ikke som en løsning på ovennævnte problem med uoverskuelighed i konferencer med mange tråde og undertråde. Kernen i det problem er imidlertid, at det ikke kan løses og næppe skal løses. Det er som bekendt ikke alle dialoger og heller ikke al læring, der kan eller skal foregå som en velordnet proces. I mundtlige dialoger har vi som regel ikke svært ved at acceptere et kaotisk aspekt, og det er i vekslende grad også tilstede i tilstedeværelsesundervisningen, hvad enten det nu er integreret i selve undervisningen, er henvist til gruppediskussioner, eller foregår uformelt i pauser og lignende sociale situationer. Som nævnt er disse dialoger væsentlige for meningsforhandlinger, men de er ofte et "tavst" og ubevidst element i uddannelser i den forstand, at de er integreret i uddannelseskulturen som vaner (Jessen 2005). I online-undervisning mangler sådanne vaner af gode grunde, og online-kommunikation, der har den mundtlige dialogs 
karakter, virker derfor umiddelbart ekstremt kaotisk, og i særlig grad, når det anvendte kommunikationsredskab medvirker til at forstærke kaos, som det er tilfældet med elektroniske konferencer. Set udefra er kommunikationen i blogs lige så uoverskuelig, men som aktiv blogger har man ikke denne oplevelse, fordi man føler sig som deltager i en løbende samtale. Blogs er bedre redskaber til at håndtere det kaotiske og uoverskuelige, netop fordi de har nogle centrale træk til fælles med samtalen, som det personlige afsæt, og det faktum, at indlæg i bogstavelig forstand hele tiden falder bagud og erstattes af nye, aktuelle ytringer. Weblogs er kendetegnet ved at danne åbne kommunikationssystemer, der hele tiden er fremadrettede, på vej mod nye ytringer. Fra en sprog- og kommunikationsteoretisk synsvinkel kan de betegnes som strikt "dialogiske” med et begreb hentet fra litteratur- og sprogforskeren Bakhtin, for hvem sproget kun kan eksistere som konkrete ytringer udsagt af personer. Enhver af disse ytringer er samtidig altid en respons både på tidligere og på kommende ytringer i en løbende kommunikationskæde (Bakhtin 1986). Der findes således ingen frit svævende ytringer, hverken i mundtlig eller skriftlig form, men kun et væv af ytringer som hele tiden svarer på hinanden. Den franske litteraturteoretiker Kristiva har på baggrund af Bakhtin navngivet dette som "intertekstualitet”. Med blogs bliver det dialogiske og intertekstuelle synligt, både i den tekniske opbygning og i den konkrete anvendelse. En post i en blog er således ikke en kommentar, men en selvstændig ytring, der indoptager de foregående poster og som på sin side igen er rettet mod nye poster i en åben og fortløbende dialog. Teknikken i trackback er på sin vis en materialisering af det dialogiske i Bakhtins forstand (om Bakhtin og online-dialoger, se Andreasen 2004).

Der er mange eksempler på, at konferencer kan anvendes til både uformelle og kaotiske dialoger, men det stiller store krav til brugernes overblik og evne til at fokusere på tværs af diskussionstråde, og i sådanne tilfælde vrides brugen af konferencer ud over, hvad redskabet kan bære. Elektroniske konferencer er teknisk set ikke det rette værktøj til denne type kommunikation. Der er en tendens til, at dialogerne formaliseres og regelsættes, fordi man derved sikrer en vis overskuelighed både for undervisere og studerende. Der er dermed en potentiel risiko for, at online-dialoger ensrettes formmæssigt på en måde, som også lægger indholdsmæssige bånd på ytringerne. Tilsvarende er der risiko for, at de studerendes samarbejde i online-undervisning alene bliver baseret på formaliserede kommunikations- og arbejdsformer, mens løsere fællesskaber, der dannes uformelt og ad hoc ud fra umiddelbare interesser, ikke etableres.

\section{Praksis}

Det vil være naturligt at spørge, om de ovennævnte fordele ved blogs nu også viser sig i praksis i forbindelse med online-undervisning. Det korte svar er naturligvis, at det ikke uden videre er tilfældet, for weblogs er lige så lidt som andre kommunikationsværktøjer et vidundermiddel, hvor teknikken løser pædagogiske eller kommunikative problemer. Blogs repræsenterer i stedet nogle nye muligheder, hvis potentialer først folder sig ud i et samspil mellem teknikken og den konkrete brug. Blogs er blevet afprøvet i to omgang i korte forløb i 2002 og 2003 under den tværinstitutionelle masteruddannelse i IKT og læring, MIL (http://www.hum.aau.dk/mil/), hvor de studerende alle blev pålagt at blogge i tre-fire uger. Formålet var ikke at teste og undersøge de pædagogiske muligheder for blogs i online-undervisning, men at præsentere et nyt kommunikationsværktøj for de studerende, hvilket på en IKT-uddannelse naturligvis i sig selv er fagligt relevant emne. Dertil kommer, at det anvendte blogsystem, Movable Type, endnu ikke indeholdt automatisk trackback og teknisk set på flere punkter endnu ikke var så brugervenligt, som blog-systemerne er i dag. Det var eksempelvis ikke muligt for deltagerne at etablere egne fællesskaber som i fx Live Journal. Erfaringerne, der kort omtales nedenfor, skal derfor tages med et gran salt.

Omkring halvdelen af de studerende fandt umiddelbart blogs spændende og brugbare til onlinekommunikation, trods de tekniske mangler. De så blogs som et godt alternativ og supplement til elektroniske konferencer, og mange fandt formen mere fleksibel, bl.a. fordi der var plads for både 
korte og lange indlæg samt for mere personlige overvejelser. Mange fandt i den forbindelse blogs velegnede som redskab til en personlig faglig refleksion i form af en virtuel portfolio, som kunne rumme de tanker, ideer og indfald, der løbende meldte sig under deres studie, men som de normalt holdt tilbage i online-kommunikationen, fordi de forekom at være uvedkommende fyld, som ikke havde interesse for andre studerende. Det er indlysende, at netop sådanne personlige portfolio'er er velegnede til at skabe dialoger om emner, som ellers ikke behandles online, alene af den grund at de gør sådanne emner synlige.

Succesen var imidlertid mere mådelig hos den anden halvdel. Nogle studerende fandt ligefrem, at kommunikationsformen var dybt egocentrisk, fordi den krævede, at deltagerne skulle træde frem som personer. Det sidstnævnte er et væsentlig korrektiv til det, der ovenfor er anført om, at fordelene ved blogs netop er det personcentrerede. Ikke alle studerende er interesserede i at træde åbent frem, slet ikke på skrift, og de foretrækker konferencerne, hvor den enkelte bedre kan skjule sig i mængden af tråde og indlæg. Dette er ikke principielt forskelligt fra, hvad man kan møde i tilstedeværelsesundervisningen, hvor der også er ganske stor forskel på, hvilke roller og kommunikationsformer deltagerne har det bedst med. Alt andet ufortalt peger det på behovet for en flerhed af asynkrone kommunikationsredskaber i online-undervisning, således at de studerende har nogle valgmuligheder, både i forhold til hvad de personligt foretrækker, og ud fra hvad den konkrete situation kræver. Her er blogs et supplement til konferencer og e-mail.

For den halvdel af de studerende, der fandt blogs var mindre anvendelige, var det generelle problem, at kommunikationen virkede forvirrende og uoverskuelig. En del af dette kan tilskrives det faktum, at de tekniske forudsætninger som nævnt ikke var optimale, men det væsentligste problem viste sig dog at være et andet. Langt de fleste af de studerende var relativt nye brugere af konferencesystemer, og de havde det foregående studieår brugt tid og kræfter på at tilegne sig denne kommunikationsform. Det største problem for mange var derfor selve skiftet til et nyt redskab med en anderledes kommunikationslogik. Trods en grundig introduktion prøvede en del af de studerende således at assimilere det nye til kendte skemaer i form af forsøg på at anvende blogs, som om der var tale om et konferencesystem med tråde og kommentarer, naturligvis med en vis frustration til følge. Erfaringerne med elektroniske konferencer er ofte tilsvarende, og mange ad de studerende var forud for projektet generelt også frustrerede og kritiske overfor det konferencesystem, der anvendes i uddannelsen.

Det er en almen erfaring fra online-undervisning, at kommunikationen mellem de studerende kan have svære vilkår. Dialogerne skal ofte initieres, ligesom de studerende skal bruge tid på at tilegne sig de nødvendige kommunikative og adfærdsmæssige kompetencer. Med blogs er det altså ikke anderledes, men ganske som med elektroniske konferencer viser praksis på internettet, at weblogs kan være velegnede kommunikationsredskaber, når begyndervanskelighederne er trådt i baggrunden. Anvendelsen af blogs i online-undervisningen betyder selvfølgelig, at de studerende og underviserne skal lære endnu et redskab at kende. Om det er arbejdet og tiden værd må vurderes ud fra den værdi som de nye dialogiske potentialer og en større fleksibilitet i asynkron kommunikation kan have for online-undervisning.

Hvis læseren er interesseret i at se nærmere på weblogs i relation til undervisning kan et sted at starte være e-Learning Centre's Guide to e-Learning (jf. litteraturlisten), hvorfra der er links til såvel praktiske anvisninger som beskrivelser af projekter. 


\section{Litteratur}

Andreasen, L.B. Samarbejde i virtuelle læringsmiljøer - med skriftlig dialog som interaktionsform. Ph.d.-afhandling. Danmarks Pædagogiske Universitet, 2004.

Bakhtin, M. M. The dialogic imagination. Austin: Univ. of Texas Press, 1986.

Blood, R. We've Got Blog: How Weblogs Are Changing Our Culture. Perseus Publishing, 2003.

Brooks, K., Nichols, C., \& Priebe, S. „Remediation, Genre, and Motivation: Key Concepts for Teaching with Weblogs”. I: L. Gurak, S. Antonijevic, L. Johnson, C. Ratliff, and J. Reyman (Eds.). Into the Blogosphere: Rhetoric, Community, and Culture of Weblogs. Los Alamitos: IEEE, $2002<$ http://blog.lib.umn.edu/blogosphere> (accessed 20.0.1.05)

Efimova, L. \& Hendrick, S. . In search for a virtual settlement. An exploration of weblog community boundaries. $2004<$ https://doc.telin.nl/dscgi/ds.py/Get/File-46041> (accessed 23.01.05)

e-Learning Centre. Guide to e-Learning. 2-10 Blogging and RSS. <http://www.elearningcentre.co.uk/sample/index.htm> (accessed 04.02.05)

Farmer, J. Communication dynamics: Discussion boards, weblogs and the development of communities of inquiry in online learning environments. 2004. $<$ http://www.ascilite.org.au/conferences/perth04/procs/farmer.html> (accessed 12.12.04)

Fiedler, S.” Introducing disruptive technologies for learning: Personal Webpublishing and Weblogs”. I: L. Cantoni \& C. McLoughlin (Eds.) Proceedings of Ed-Media 2004 (pp. 25842591). Lugano, Switzerland: Association for the Advancement of Computing in Education (AACE), 2004.

Garrison, R. \& Anderson, T.. E-Learning in the 21st Century: A framework for research and practice. Routledge, 2003.

Jessen, C. Tavs viden, uddannelseskultur og virtuelle leringsrum. Working Paper. Forskningsprogrammet medier og it i læringsperspektiv, Danmarks Pædagogiske Universitet (under udgivelse).

Paulsen, M. F. "Online Education Systems in Scandinavian and Australian Universities: A Comparative Study”. I: The International Review of Research in Open and Distance Learning. Volume 3, Number 2, 2002.

Pilgrim, M. What is RSS?2002. <http://www.xml.com/pub/a/2002/12/18/dive-into-xml.html> (accessed 12.01.05)

Raynes-Goldie, K. 2004. Pulling sense out of today's informational chaos: LiveJournal as a site of knowledge creation and sharing. First Monday, volume 9, number 12 (December 2004), http://firstmonday.org/issues/issue9_12/raynes/index.html (accessed 14.01.05)

Scott, J. 2000. Social network analysis: a handbook. Sage Publications

Sorensen, E. K. \& Takle, E. S. 2002. Collaborative Knowledge Building in Web-based Learning : Assessing the Quality of Dialogue. The International Journal on E-Learning (IJEL) : 2002 ; 1 , 1. - s. 28-32 (1537-2456)

Wikipedia. 2004. Weblog. <http://www.wikipedia.org> (accessed 14.01.05)

Willis, C. \& Bowman, S. 2004. We Media. $<$ http://ww.mediacenter.org/mediacenter/research/wemedia/> (accessed 14.01.05)

Dave Winer, D. u.å. The History of Weblogs. <http://newhome.weblogs.com/historyOfWeblogs> (accessed 10.01.05) 